\title{
Effect of Basal Medium, Explants Size and Density on the In Vitro Proliferation and Growth of Date Palm (Phoenix dactylifera L.) Cultivar '16-bis'
}

\author{
Mouaad Amine MAZRI \\ INRA, CRRA Marrakech, UR Agro-Biotechnologie, Avenue Mohammed VI, B.P. 533, Marrakech, Morocco; m.a.mazri@gmail.com
}

\begin{abstract}
The effect of basal medium, explant size and density on shoot multiplication, growth, rooting and acclimatization of date palm cv. '16-bis' was evaluated. Bud clusters of different sizes (2, 3, 4 and 5 buds per cluster) were cultured at density of 1, 2, 3 and 4 clusters on Murashige and Skoog medium (MS), woody plant medium (WPM) and Nitsch medium (NM) supplemented with $0.5 \mathrm{mg} / \mathrm{L}$ 2-naphthoxyacetic acid and $0.5 \mathrm{mg} / \mathrm{L}$ kinetin for three months (multiplication phase). Separated shoots of different sizes ( $<3 \mathrm{~cm}$; 3 to $4.5 \mathrm{~cm}$ and 4.5 to $6 \mathrm{~cm}$ ) were cultured at density of 1,2,3 and 4 shoots on hormone free MS medium, WPM or NM for three months (Elongation-rooting phase). The proliferation and development of shoots were affected by the basal medium, explant size and density. The optimal shoot proliferation (18.1) was observed when 4 buds clusters were cultured at the density of 2 clusters per jar in MS medium. Separated shoots of 4.5 to $6 \mathrm{~cm}$ length exhibited the optimal in vitro development in terms of leaf length and greening, and root number and length when cultured on MS medium. In addition, these shoots reached the highest acclimation frequency with $80 \%$. Our results would be utilized for an efficient propagation of plantlets of cv. '16-bis', a selected date palm cultivar resistant to the bayoud disease.
\end{abstract}

Keywords: acclimatization, organogenesis, Phoenix dactylifera L., regeneration, shoot multiplication

\section{Introduction}

Date palm (Phoenix dactylifera L.) is one of the most important fruit crops in the Middle East and North Africa. In Morocco, it is the main component of oasis ecosystems, where it provides food, shelter, fiber and other products. However, its population has been reduced significantly because of a very serious disease called bayoud (Sedra, 2011).

The bayoud disease caused by a filamentous imperfect fungus (Fusarium oxysporum f. sp. albedinis) (Quenzar $e t$ al., 2001) is by far the most dangerous disease affecting date palm plantations (Sedra and Lazrak, 2011). In Morocco, the majority of the date palm groves are affected by this fungus (Quenzar et al., 2001). Up to now, the only feasible method to combat bayoud disease and rehabilitate Moroccan palm groves is the selection, multiplication then the diffusion of resistant cultivars (Sedra, 2011).

The use of in vitro culture techniques would multiply selected genotype on a large-scale and in short period (Jain, 2012). Somatic embryogenesis is commonly used for the rapid propagation of date palm cultivars. However, undesirable genetic variability was observed in the regenerated plants (Khierallah and Bader, 2007). Regeneration through direct organogenesis has the advantage of using low concentrations of plant growth regulators and avoiding the callus phase, which minimize the risk of somaclonal variation among regenerants. However, the success of this technique is highly genotypic dependent (Jain, 2012).

In this study, we aimed to evaluate the effect of basal medium, explant size and density on shoots proliferation and growth of the Moroccan date palm cultivar resistant to bayoud '16-bis', in order to optimize conditions for an efficient micropropagation and regeneration through organogenesis.

\section{Materials and methods}

\section{Initiation and maintenance of organogenic cultures}

Organogenic cultures of date palm cv. '16-bis' were initially established from shoot-tip explants according to the protocol of Beauchesne et al. (1986). Organogenic cultures were then cultured on three different basal media: MS (Murashige and Skoog, 1962), WPM (Lloyd and McCown, 1980) and NM (Nitsch and Nitsch, 1969). All media were supplemented with $30 \mathrm{~g} / \mathrm{L}$ sucrose, $1 \mathrm{~g} / \mathrm{L}$ polyvinyl-pyrrolidone and gelled with $6 \mathrm{~g} / \mathrm{L}$ bactoagar.

\section{Experiment 1: Effect of explants size on shoot proliferation}

In the first experiment, the effect of four explant sizes on shoot proliferation was evaluated. Buds $(<1 \mathrm{~cm}$ length) from the organogenic cultures were separated into clusters of 2, 3, 4 and 5 buds (Fig. 1a). The clusters were cultured for three months at density of 1 per jar onto MS, 
WPM and NM media for multiplication. All multiplication media were supplemented with $30 \mathrm{~g} / \mathrm{L}$ sucrose, $1 \mathrm{~g} / \mathrm{L}$ polyvinyl-pyrrolidone, $0.5 \mathrm{mg} / \mathrm{L}$ 2-naphthoxyacetic acid, $0.5 \mathrm{mg} / \mathrm{L}$ kinetin and gelled with $6 \mathrm{~g} / \mathrm{L}$ bactoagar.

\section{Experiment 2: Effect of explants density on shoot proliferation}

In the second experiment, the effect of four densities of explants on shoot proliferation was studied. Clusters comprised 4 buds each were cultured onto the same multiplication media of the first experiment for three months at density of 1, 2, 3 and 4 clusters per jar.

\section{Experiment 3: Effect of explants size on shoot length and} rooting

In the third experiment, the effect of three shoot size $(<3 \mathrm{~cm} ; 3$ to $4.5 \mathrm{~cm}$ and 4.5 to $6 \mathrm{~cm}$; Fig. $1 \mathrm{~b})$ on shoot length and rooting was tested. Shoots (with one root $<1$ $\mathrm{cm}$ length; Fig. 1b) were isolated from the mother cluster and cultured individually for three months onto elonga- tion-rooting media; i.e. hormone-free MS, WPM or NM. Media were supplemented with $30 \mathrm{~g} / \mathrm{L}$ sucrose, $1 \mathrm{~g} / \mathrm{L}$ polyvinyl-pyrrolidone and gelled with $6 \mathrm{~g} / \mathrm{L}$ bactoagar.

\section{Experiment 4: Effect of explants density on shoot length} and rooting

In this experiment, shoots of 4.5 to $6 \mathrm{~cm}$ length were separated from the mother clusters and cultured at density of 1, 2, 3 and 4 shoots per jar. The elongation-rooting media were the same as experiment 3 . Shoots were cultured in these media for three months.

\section{Plantlets acclimatization}

Plantlets with three leaves and good root system were removed from the culture media. The root system was carefully washed under tap water to remove residual media then soaked in a fungicide solution ( $1 \mathrm{~g} / \mathrm{L}$ Pelt $44 \mathrm{PM})$ for $15 \mathrm{~min}$. Acclimatization of the plantlets was done in a mixture of peat and gravel $(1: 1, \mathrm{v}: \mathrm{v})$ in a tunnel covered with polyethylene and placed in a glasshouse. After two
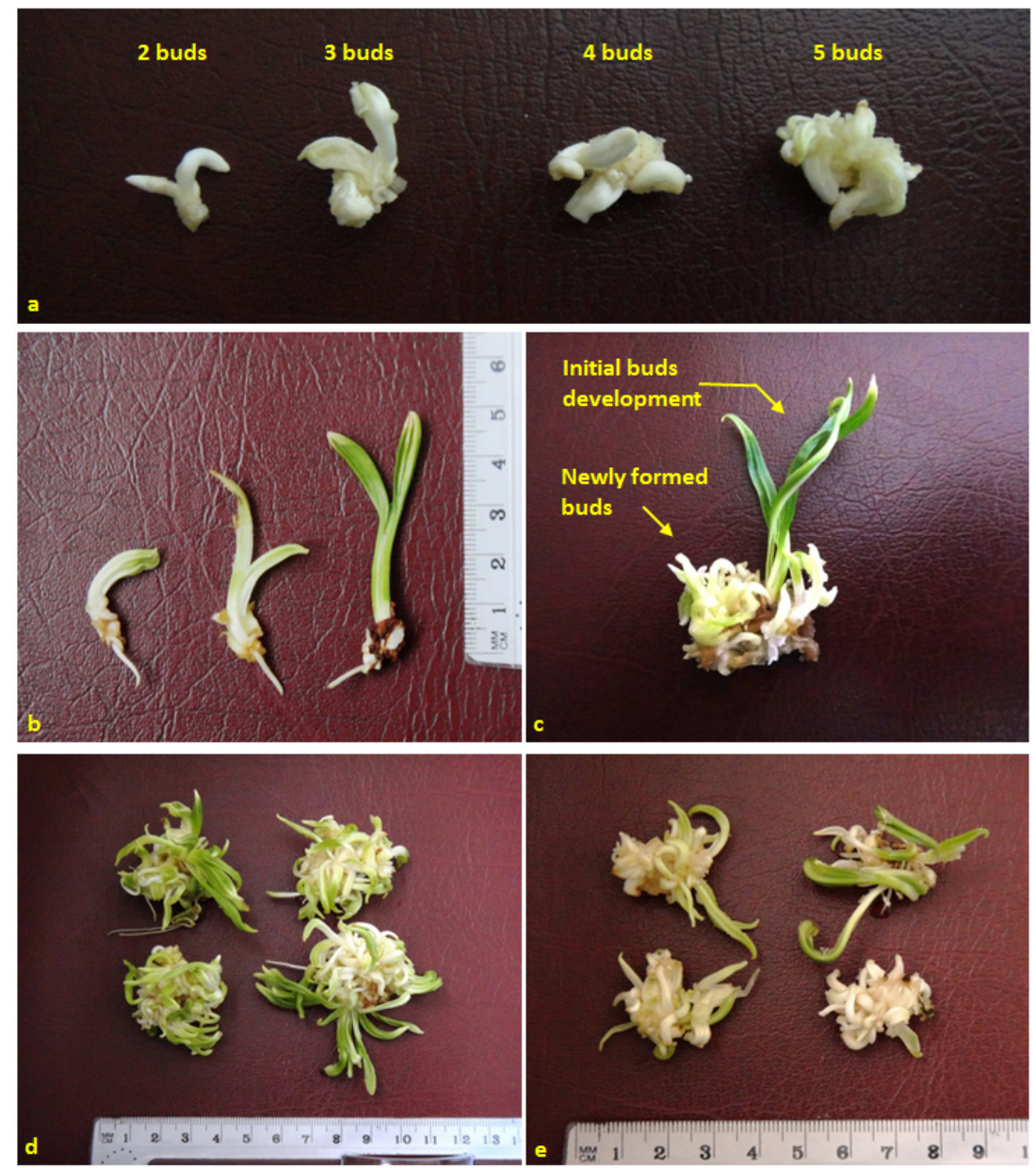

Fig. 1. General aspects of shoot multiplication from clusters of different sizes. a Clusters of 2, 3, 4 and 5 buds used in this study; b Shoots of different sizes used during the elongation-rooting phase; c Shoot multiplication after 3 months of culture. This cluster was initially comprised 2 buds. Note the difference in growth between the initial buds and the newly formed ones; $d$ Example of shoot multiplication after 3 months of culture when clusters comprised initially 4 buds and cultured at the density of 2 per jar; e Example of shoot multiplication after 3 months of culture when clusters comprised initially 4 buds and cultured at the density of 4 per jar 
334

weeks, the polyethylene was opened gradually. The polyethylene was removed completely after four weeks. Inside the polyethylene tunnel relative humidity was $98 \%$ while it was $70 \%$ in the glasshouse.

\section{Culture conditions}

All culture media were adjusted to $\mathrm{pH} 5.7$ then 25 $\mathrm{ml}$ aliquots of culture medium were dispensed into jars. Media were autoclaved at $121^{\circ} \mathrm{C}$ for $25 \mathrm{~min}$. All cultures were incubated under a $16 \mathrm{~h}$ light $/ 8 \mathrm{~h}$ dark photoperiod at $25^{\circ} \mathrm{C}$ and transferred onto fresh medium every month. Plantlets transferred to the glasshouse for acclimatization were kept at $27^{\circ} \mathrm{C}$ under natural light.

\section{Parameters recorded and statistical analysis}

In experiments 1 and 2, the average number of shoots per explant and average shoot length were calculated after three months of culture. In experiments 3 and 4, we recorded the average length of shoots, leaf greening (leaf greening was visually estimated and noted,+++ and +++ for low, moderate and high intensity, respectively), average number of roots and length of roots after three months. Concerning the plants acclimatization, the survival rate was calculated after three months of culture in the glasshouse. In all experiments, each jar was considered as one replicate and the data represent the mean of ten replicates.

Analysis of variables was carried out using a completely randomized design at 5\% significant level of SPSS version 16.0. Differences between means were separated with Student-Newman-Keuls test. Prior to analysis, percentage data were arcsine transformed.

\section{Results}

\section{Effect of explants size on shoot proliferation}

The explant size had a significant effect on shoot proliferation. When clusters of two buds were cultured onto proliferation medium, we observed buds elongation and greening. The formation of new buds was observed at the base of the elongated buds after the first transfer onto fresh medium (i.e. after one month of culture). After three months of culture, the number of newly formed buds was low: 12.2, 9.3 and 10.4 in MS, WPM and NM, respectively (Fig. 1c).

Four buds per cluster was the most suitable size for high shoot proliferation with averages of 21.5, 14.7 and 16.3 morphologically superior shoots per explant in MS, WPM and NM, respectively (Tab. 1). Clusters of 5 buds have also displayed high shoot proliferation. However, a pronounced tissue browning was observed.

\section{Effect of explants density on shoot proliferation}

The highest number of shoots per cluster was obtained when the density used was one cluster per jar $(21.5,14.7$ and 16.3 shoots per explant in MS, WPM and NM, respectively). However, taking into consideration the number of shoots regenerated per jar (Tab. 2) and their morphology, we strongly suggest the use of 2 clusters per jar of MS medium.

When 3 and 4 clusters were cultured per jar, the average number of shoots regenerated per jar could be increased (Tab. 2). However, the shoots developed at the densities of 1 and 2 clusters per jar were morphologically superior. They were healthy and more uniform (Fig. 1d) while those

Tab. 1. Effect of basal medium and initial number of buds per cluster on shoot multiplication and length of date palm cv. '16-bis' after 3 months of culture

\begin{tabular}{cccccccccccccc}
\hline Culture medium & \multicolumn{1}{c}{ MS } & \multicolumn{1}{c}{ WPM } & NM \\
\hline $\begin{array}{c}\text { Initial number of } \\
\text { buds per cluster }\end{array}$ & $2 \mathrm{buds}$ & $3 \mathrm{buds}$ & $4 \mathrm{buds}$ & $5 \mathrm{buds}$ & $2 \mathrm{buds}$ & $3 \mathrm{buds}$ & $4 \mathrm{buds}$ & $5 \mathrm{buds}$ & $2 \mathrm{buds}$ & $3 \mathrm{buds}$ & $4 \mathrm{buds}$ & $5 \mathrm{buds}$ \\
Average number of & $12.2 \pm$ & $17.4 \pm$ & $21.5 \pm$ & $20.4 \pm$ & $9.3 \pm$ & $12.2 \pm$ & $14.7 \pm$ & $14.5 \pm$ & $10.4 \pm$ & $13.3 \pm$ & $16.3 \pm$ & $17.1 \pm$ \\
shoots after 3 months & $1.8 \mathrm{abc}$ & $2.2 \mathrm{e}$ & $2.5 \mathrm{f}$ & $3.5 \mathrm{f}$ & $2.7 \mathrm{a}$ & $1.8 \mathrm{abc}$ & $1.7 \mathrm{cde}$ & $3.6 \mathrm{cde}$ & $1.7 \mathrm{ab}$ & $3.0 \mathrm{bcd}$ & $4.7 \mathrm{de}$ & $3.8 \mathrm{e}$ \\
$\begin{array}{c}\text { Average length } \\
\text { of shoots }(\mathrm{cm})\end{array}$ & $5.1 \pm$ & $4.3 \pm$ & $3.1 \pm$ & $3.2 \pm$ & $4.1 \pm$ & $3.5 \pm$ & $2.3 \pm$ & $2.2 \pm$ & $3.1 \pm$ & $3.2 \pm$ & $2.7 \pm$ & $2.6 \pm$ \\
\hline
\end{tabular}

Note: Mean values with the same letters are not significantly different $(p>0.05)$

Tab. 2. Effect of basal medium and number of clusters per jar (explant density) on shoot multiplication and length of date palm cv. '16-bis' after 3 months of culture

\begin{tabular}{ccccccccccccc}
\hline Culture medium & \multicolumn{4}{c}{ MS } & \multicolumn{1}{c}{ WPM } & \multicolumn{4}{c}{ NM } \\
\hline \multirow{2}{*}{ Explant density } & $\begin{array}{c}1 \\
\text { cluster }\end{array}$ & $\begin{array}{c}2 \\
\text { cluster }\end{array}$ & $\begin{array}{c}3 \\
\text { cluster }\end{array}$ & $\begin{array}{c}4 \\
\text { cluster }\end{array}$ & $\begin{array}{c}1 \\
\text { cluster }\end{array}$ & $\begin{array}{c}2 \\
\text { cluster }\end{array}$ & $\begin{array}{c}3 \\
\text { cluster }\end{array}$ & $\begin{array}{c}4 \\
\text { cluster }\end{array}$ & $\begin{array}{c}1 \\
\text { cluster }\end{array}$ & $\begin{array}{c}2 \\
\text { cluster }\end{array}$ & $\begin{array}{c}3 \\
\text { cluster }\end{array}$ & $\begin{array}{c}4 \\
\text { cluster }\end{array}$ \\
\hline Average number of shoots & $21.5 \pm$ & $18.1 \pm$ & $12.5 \pm$ & $10.7 \pm$ & $14.7 \pm$ & $9.4 \pm$ & $7.3 \pm$ & $7.4 \pm$ & $16.3 \pm$ & $12.2 \pm$ & $8.3 \pm$ & $7.7 \pm$ \\
per cluster after 3 months & $2.5 \mathrm{f}$ & $2.7 \mathrm{e}$ & $2.6 \mathrm{c}$ & $1.6 \mathrm{bc}$ & $1.7 \mathrm{~d}$ & $1.1 \mathrm{ab}$ & $1.4 \mathrm{a}$ & $1.7 \mathrm{a}$ & $4.7 \mathrm{de}$ & $1.3 \mathrm{c}$ & $2.0 \mathrm{ab}$ & $1.4 \mathrm{a}$ \\
Average number of shoots & $21.5 \pm$ & $36.2 \pm$ & $37.5 \pm$ & $42.8 \pm$ & $14.7 \pm$ & $18.8 \pm$ & $21.9 \pm$ & $29.6 \pm$ & $16.3 \pm$ & $24.4 \pm$ & $24.9 \pm$ & $30.8 \pm$ \\
per jar after 3 months & $2.5 \mathrm{bc}$ & $5.5 \mathrm{f}$ & $7.9 \mathrm{f}$ & $6.5 \mathrm{~g}$ & $1.7 \mathrm{a}$ & $2.3 \mathrm{abc}$ & $4.4 \mathrm{bc}$ & $6.8 \mathrm{de}$ & $4.7 \mathrm{ab}$ & $2.6 \mathrm{~cd}$ & $6.0 \mathrm{~cd}$ & $5.9 \mathrm{e}$ \\
Average length of & $3.1 \pm$ & $2.6 \pm$ & $2.3 \pm$ & $2.5 \pm$ & $2.3 \pm$ & $2.5 \pm$ & $2.7 \pm$ & $2.5 \pm$ & $2.7 \pm$ & $2.3 \pm$ & $2.3 \pm$ & $2.4 \pm$ \\
shoots $(\mathrm{cm})$ & $1.6 \mathrm{a}$ & $1.4 \mathrm{a}$ & $1.7 \mathrm{a}$ & $1.0 \mathrm{a}$ & $0.9 \mathrm{a}$ & $1.7 \mathrm{a}$ & $1.4 \mathrm{a}$ & $1.3 \mathrm{a}$ & $0.4 \mathrm{a}$ & $1.0 \mathrm{a}$ & $1.0 \mathrm{a}$ & $0.9 \mathrm{a}$ \\
\hline
\end{tabular}

Note: Mean values with the same letters are not significantly different $(p>0.05)$ 
formed at the densities of 3 and 4 clusters per jar (Fig. 1e) showed morphological abnormalities (i.e. hyperhydricity and tissue browning; data not shown). Thus, a density of 2 clusters per jar is optimal in terms of cost and to avoid morphological abnormalities.

\section{Effect of explants size on shoot length and rooting}

The pattern of shoot growth and development was influenced by the explant size and the basal medium. Our findings showed that the optimum growth and development of shoots in terms of length and rooting was obtained in shoots from 4.5 to $6 \mathrm{~cm}$ length: In MS medium, the average shoot length was $14.2 \mathrm{~cm}$, the average number of roots per shoot was 4.2 and their average length was 5 $\mathrm{cm}$. In WPM and NM media, we observed lower averages: 11.8 and $10.7 \mathrm{~cm}$ shoot length, respectively; 3.4 roots per shoot in both the basal media; 3.5 and $3.4 \mathrm{~cm}$ root length in WPM and NM, respectively. Concerning the other sizes, shoots lower than $3 \mathrm{~cm}$ showed slow growth. Intermediate results were observed within shoots from 3 to 4.5 cm length (Tab. 3). Regardless of the initial shoot length, we observed that shoot greening intensity was higher in MS medium. This indicates that those plantlets have good photosynthetic capacity and consequently, better chance of survival during acclimatization (Mazri and Meziani, 2013)
Effect of explants density on shoot length, rooting and acclimatization

Increasing shoots density in the culture medium decreased shoot length, and root number and length in all the culture media. The highest length of shoots, the highest number of roots per shoot and their highest length were observed at the density of one shoot per jar. Nevertheless, the density of 2 shoots per jar also showed good development. For example, average values of $13.7 \mathrm{~cm}$ for shoot length, 4.3 for average number of roots per shoot and $4.3 \mathrm{~cm}$ for root length were noted at the density of 2 shoots per jar in MS medium. Shoots cultured at the densities of 3 and 4 per jar showed lower values (Tab. 4).

Shoots at the three leaves stage were transferred to the glasshouse. After three months under glasshouse conditions, more than $60 \%$ of plantlets survived (Tab. 4). The highest survival rate $(80 \%)$ was observed in shoots that have been cultured onto MS medium at the densities of 1 and 2 shoots per jar. Thus, to save cost, we suggest the density of 2 shoots per jar during the elongation-rooting phase. The plantlets that survived grew vigorously and did not show any morphological abnormalities (Fig. 2).

\section{Discussion}

Plant growth and development under in vitro conditions depend upon different factors such as the genotype,

Tab. 3. Effect of basal medium and initial shoot length $(\mathrm{cm})$ on shoot growth and development of date palm cv. '16-bis' after 3 months of culture

\begin{tabular}{|c|c|c|c|c|c|c|c|c|c|}
\hline Culture medium & & MS & & & WPM & & & NM & \\
\hline $\begin{array}{l}\text { Initial shoot } \\
\text { length }(\mathrm{cm})\end{array}$ & $<3 \mathrm{~cm}$ & $3-4.5 \mathrm{~cm}$ & $4.5-6 \mathrm{~cm}$ & $<3 \mathrm{~cm}$ & $3-4.5 \mathrm{~cm}$ & $4.5-6 \mathrm{~cm}$ & $<3 \mathrm{~cm}$ & $3-4.5 \mathrm{~cm}$ & $4.5-6 \mathrm{~cm}$ \\
\hline $\begin{array}{l}\text { Shoot length after } \\
3 \text { months }(\mathrm{cm})\end{array}$ & $10.4 \pm 2.3 \mathrm{ab}$ & $11.7 \pm 2.2 \mathrm{~b}$ & $14.2 \pm 2.0 \mathrm{c}$ & $9.2 \pm 1.9 \mathrm{a}$ & $11.0 \pm 0.8 \mathrm{ab}$ & $11.8 \pm 1.3 \mathrm{~b}$ & $9.3 \pm 1.7 \mathrm{a}$ & $9.7 \pm 1.4 \mathrm{ab}$ & $10.7 \pm 1.8 \mathrm{ab}$ \\
\hline Shoot greening & +++ & +++ & +++ & ++ & ++ & ++ & ++ & ++ & ++ \\
\hline Root number & $3.3 \pm 1.3 \mathrm{ab}$ & $3.3 \pm 0.6 \mathrm{ab}$ & $4.2 \pm 1.0 \mathrm{~b}$ & $3.2 \pm 0.6 \mathrm{ab}$ & $3.2 \pm 0.6 \mathrm{ab}$ & $3.4 \pm 0.5 \mathrm{ab}$ & $3.0 \pm 0.8 \mathrm{a}$ & $3.2 \pm 0.6 \mathrm{ab}$ & $3.4 \pm 0.8 \mathrm{ab}$ \\
\hline Root length $(\mathrm{cm})$ & $3.2 \pm 0.6 \mathrm{ab}$ & $4.3 \pm 0.4 \mathrm{ab}$ & $5.0 \pm 0.4 c$ & $2.5 \pm 0.8 \mathrm{a}$ & $2.6 \pm 1.5 \mathrm{a}$ & $3.5 \pm 1.5 \mathrm{ab}$ & $2.4 \pm 0.8 \mathrm{a}$ & $3.1 \pm 1.4 \mathrm{ab}$ & $3.4 \pm 1.2 \mathrm{ab}$ \\
\hline
\end{tabular}

Note: Mean values with the same letters are not significantly different $(p>0.05)$. Intensity of greening: + low, ++ moderate, +++ high

Tab. 4. Effect of basal medium and number of shoots per jar (shoot density) on shoot growth, development and acclimatization of date palm cv. '16-bis' after 3 months of culture

\begin{tabular}{ccccccccccccccc}
\hline Culture medium & \multicolumn{1}{c}{ MS } & \multicolumn{1}{c}{ WPM } & \multicolumn{4}{c}{ NM } \\
\hline \multirow{2}{*}{ Shoot Density } & 1 & 2 & 3 & 4 & 1 & 2 & 3 & 4 & 1 & 2 & 3 & 4 \\
& Shoot & Shoots & Shoots & Shoots & Shoot & Shoots & Shoots & Shoots & Shoot & Shoots & Shoots & Shoots \\
\hline Shoot length after & $14.2 \pm$ & $13.7 \pm$ & $13.3 \pm$ & $11.4 \pm$ & $11.8 \pm$ & $10.8 \pm$ & $10.6 \pm$ & $9.5 \pm$ & $10.7 \pm$ & $10.3 \pm$ & $9.5 \pm$ & $8.6 \pm$ \\
3 months $(\mathrm{cm})$ & $2.0 \mathrm{~d}$ & $1.7 \mathrm{~d}$ & $1.3 \mathrm{~d}$ & $1.7 \mathrm{bc}$ & $1.3 \mathrm{c}$ & $1.1 \mathrm{bc}$ & $1.9 \mathrm{bc}$ & $1.3 \mathrm{ab}$ & $1.8 \mathrm{bc}$ & $1.4 \mathrm{abc}$ & $1.0 \mathrm{ab}$ & $0.5 \mathrm{a}$ \\
Shoot greening & +++ & +++ & +++ & +++ & ++ & ++ & ++ & ++ & ++ & ++ & ++ & ++ \\
Root number & $4.2 \pm$ & $4.3 \pm$ & $3.8 \pm$ & $3.2 \pm$ & $3.4 \pm$ & $3.3 \pm$ & $2.4 \pm$ & $2.3 \pm$ & $3.4 \pm$ & $3.2 \pm$ & $3.1 \pm$ & $2.9 \pm$ \\
& $1.0 \mathrm{c}$ & $1.0 \mathrm{c}$ & $0.9 \mathrm{bc}$ & $1.2 \mathrm{abc}$ & $0.5 \mathrm{abc}$ & $1.2 \mathrm{abc}$ & $0.5 \mathrm{a}$ & $0.4 \mathrm{a}$ & $0.8 \mathrm{abc}$ & $0.9 \mathrm{abc}$ & $0.7 \mathrm{abc}$ & $0.8 \mathrm{ab}$ \\
Root length $(\mathrm{cm})$ & $5.0 \pm$ & $4.3 \pm$ & $3.7 \pm$ & $2.6 \pm$ & $3.5 \pm$ & $2.5 \pm$ & $2.6 \pm$ & $2.2 \pm$ & $3.4 \pm$ & $3.1 \pm$ & $2.5 \pm$ & $2.2 \pm$ \\
Plantlet & $0.4 \mathrm{~d}$ & $0.9 \mathrm{~cd}$ & $1.1 \mathrm{bc}$ & $1.2 \mathrm{ab}$ & $1.5 \mathrm{abc}$ & $0.7 \mathrm{ab}$ & $1.0 \mathrm{ab}$ & $0.6 \mathrm{a}$ & $1.2 \mathrm{abc}$ & $1.3 \mathrm{abc}$ & $0.7 \mathrm{ab}$ & $0.4 \mathrm{a}$ \\
acclimatization $(\%)$ & $80.0 \pm$ & $80.0 \pm$ & $68.0 \pm$ & $62.0 \pm$ & $74.0 \pm$ & $72.0 \pm$ & $60.0 \pm$ & $60.0 \pm$ & $76.0 \pm$ & $74.0 \pm$ & $62.0 \pm$ & $60.0 \pm$ \\
\hline
\end{tabular}

Note: Mean values with the same letters are not significantly different $(p>0.05)$. Intensity of greening: + low, ++ moderate, +++ high 


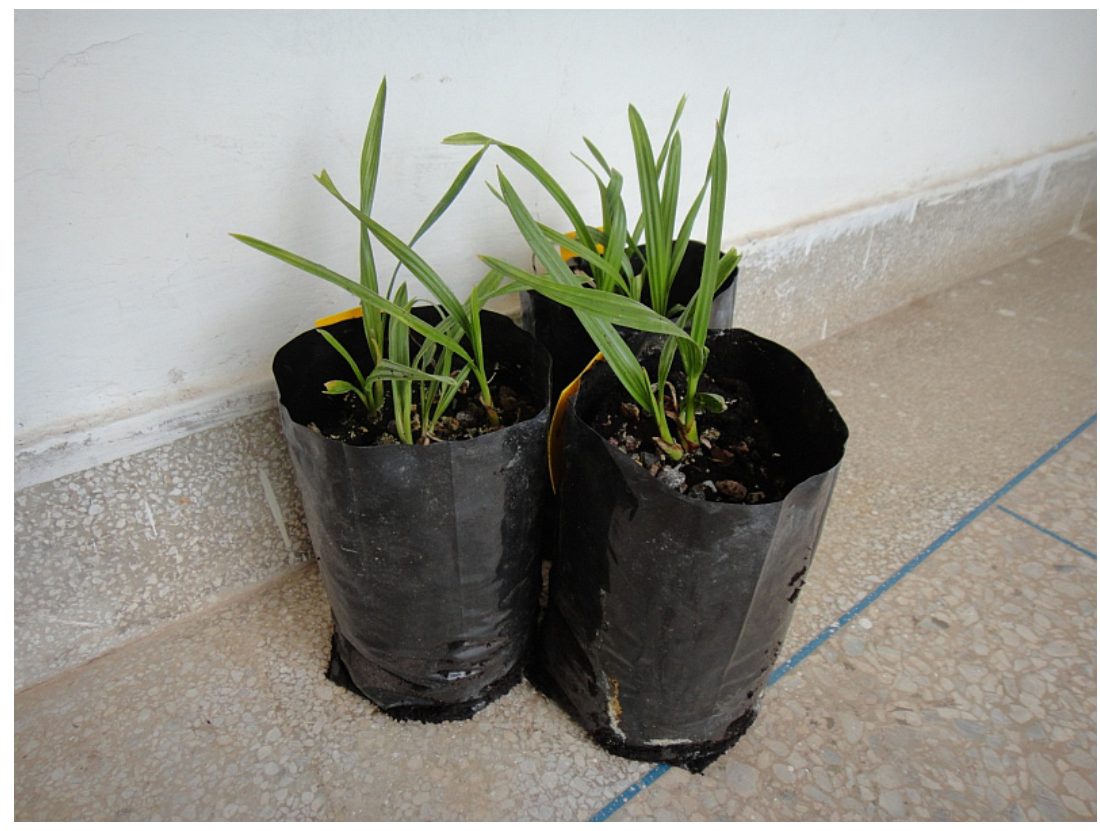

Fig. 2. Acclimatized plantlets under glasshouse conditions at 90 days after acclimatization

explant type, plant growth regulators and the basal medium (Neumann et al., 2009). It has been demonstrated that the basal medium plays a crucial role in the in vitro multiplication and regeneration of many species, such as Easter lily (Ramsay et al., 2003), Populus alba $\times$ P. berolinensis (Wang et al., 2008), and Aquilaria hirta (Hassan et al., 2011). In fact, plant micropropagation is greatly influenced by the nature of the culture medium used (George et al., 2008). In this study, the effect of three basal media on shoot proliferation, growth and development in date palm cv. '16-bis' was evaluated. The highest number of shoots per cluster, the optimum growth and development of shoots and the highest survival rate of plantlet acclimatization were obtained in MS medium. In addition, shoots that have been cultured onto MS medium were morphologically superior to those cultured onto WPM and NM media. Furthermore, shoots grown on MS medium showed higher level of greening which is important to have good photosynthetic capacity and better chance of survival during acclimatization (Mazri and Meziani, 2013). Shoot greening was influenced by the concentration of nitrogen in the culture medium (Mazri, 2012; Mazri and Meziani, 2013) which is higher in MS medium. MS medium was also used for shoot proliferation of many date palm cultivars such as cv. 'Maktoom' (Khierallah and Bader, 2007), cv. 'Barhee' (Fki et al., 2011) and cv. 'Khanezi' (Al-Khateeb, 2006; 2008).

Regardless of the basal medium, our findings indicated that the explant size and density also influence bud shoot proliferation and growth in date palm culture. To the best of our knowledge, the effect of explant size and density has not yet been reported in date palm micropropagation. Our results demonstrate that 4 buds per cluster was the optimum size for bud shoot proliferation. The size of 2 buds per cluster leaded to an undesirable early elongation of the existing buds and hampered the formation of new buds. These findings are in contrast with previous results reported by Hamad and Taha (2009) on Ananas comosus L. Merr. Increasing the number of buds per cluster to 3 or 4 improved shoot proliferation and avoid the precocious elongation, whereas the size of 5 buds per cluster caused pronounced browning in cultured explants and decreased the number of healthy looking shoots produced, which is consistent with Abahmane (2011) who suggested the use of explant of small size to prevent browning of date palm in vitro-cultured tissues. Explant density also influenced bud shoot proliferation. Increasing explants density reduced the proliferation rate per cluster. This result is in good agreement with previous results of Populus alba $\times$ P. grandidentata (Chun et al., 1986). However, Kane and Philman (1992) reported that explant density had no effect on regeneration rate per explant in Pontederia cordata L., which shows difference among species. In our case, increasing explant density showed tissue browning and hyperhydricity. Growth and development of isolated shoots was also influenced by the explant size and density. Shoots from 4.5 to $6 \mathrm{~cm}$ length exhibited rapid growth and development, especially in MS medium. Increasing shoot density decelerated their growth and development. This result showed that shoot length, and roots number and length were also influenced by differences in basal medium, shoot size and density.

Plantlets acclimatization can be considered as a major phase for successful establishment of micropropagated plantlets (Kumar and Rao, 2012). In this study, the survival rate of plantlets with no morphological abnormalities was in the range of $60 \%$ to $80 \%$. In a previous work, higher survival rate was obtained in date palm cv. 'Najda' 
under the same acclimatization protocol (Mazri and Meziani, 2013); this could highlight the genotype effect on plantlets acclimatization.

In conclusion, our results will be beneficial to optimize the conditions of the in vitro plantlet production of date palm cv. '16-bis'. This will be useful for the large-scale propagation of this cultivar resistant to Fusarium oxysporum f. sp. albedinis. As far as we know, this is the first report about cv. '16-bis' micropropagation.

\section{References}

Abahmane L (2011). Date palm micropropagation via organogenesis, 69-90 p. In: Jain SM, Al-Khayri JM, Johnson DV (Eds.). Date Palm Biotechnology, Springer, Dordrecht.

Al Khateeb AA (2006). Role of cytokinin and auxin on the multiplication stage of date palm (Phoenix dactylifera L.) cv. 'Sukry'. Biotechnol 5:349-352.

Al Khateeb AA (2008). The problems facing the use of tissue culture technique in date palm (Phoenix dactylifera L.). Sci J King Faisal Univ 9:85-104.

Beauchesne G, Zaid A, Rhiss A (1986). Meristematic potentialities of bottom of young leaves to rapidly propagate date palm. Proc of the $2^{\text {nd }}$ Symposium on the Date Palm 87-94 p.

Chun YW, Hall RB, Stephens LC (1986). Influences of medium consistency and shoot density on in vitro shoot proliferation of Populus alba $\times$ P. grandidentata. Plant Cell Tiss Org Cult 5:179-185.

Fki L, Bouaziz N, Kriaa W, Benjemaa-Masmoudi R, GargouriBouzid R, Rival A, Drira N (2011). Multiple bud cultures of 'Barhee' date palm (Phoenix dactylifera) and physiological status of regenerated plants. J Plant Physiol 168:1694-1700.

George EF, Hall MA, De Klerk GJ (2008). The components of plant tissue culture media I: macro- and micro-nutrients, 65-113 p. In: George EF, Hall MA, De Klerk GJ (Eds.). Plant Propagation by Tissue Culture 3rd edition Volume 1 The background, Dordrecht, Springer.

Hamad AM, Taha RM (2009). Effect of explant density on the in vitro proliferation and growth of separated and cluster shoots of smooth cayenne pineapple (Ananas comosus L. Merr.). Asian J Plant Sci 8(4):313-317.

Hassan NH, Ali NAM, Zainudin F, Ismail H (2011). Effect of 6-benzylaminopurine (BAP) in different basal media on shoot multiplication of Aquilaria hirta and detection of essential oils in the in vitro shoots. Afr J Biotechnol 10(51):10500-10503.

Jain SM (2012). Date palm biotechnology: Current status and prospective-an overview. Emir J Food Agric 24(5):386-399.

Kane ME, Philman NL (1992). Effect of culture vessel type on in vitro multiplication of Pontederia cordata L. Proc Fla State Hort Soc 105:213-215.
Khierallah HSM, Bader SM (2007). Micropropagation of date palm (Phoenix dactylifera L.) var. Mektoom through direct organogenesis. Acta Hort 736:213-224.

Kumar K, Rao IU (2012). Morphophysiologicals problems in acclimatization of micropropagated plants in - ex vitro conditions-a review. J Ornament Hortic Plants 2(4):271-283.

Lloyd G, McCown B (1980). Commercially feasible micropropagation of mountain laurel (Kalmia latifolia) by use of shoot tip cultures. Comb Proc Intl Soc 30:421-427.

Mazri MA (2012). Effect of liquid media and in vitro pre-acclimatization stage on shoot elongation and acclimatization of date palm (Phoenix dactylifera L.) cv. 'Najda'. J Ornament Hortic Plants 2:225-231.

Mazri MA, Meziani R (2013). An improved method for micropropagation and regeneration of date palm (Phoenix dactylifera L.). J Plant Biochem Biotechnol 22(2):176-184.

Murashige T, Skoog FA (1962). A revised medium for rapid growth and bioassays with tobacco tissue cultures. Phys Planta 15:473-479.

Neumann KH, Kumar A, Imani J (2009). Some endogenous and exogenous factors in cell culture systems, $139-160 \mathrm{p}$. In: Neumann KH, Kumar A, Imani J (Eds.). Plant cell and tissue culture - a tool in biotechnology: basics and application. Springer, Berlin.

Nitsch JP, Nitsch C (1969). Haploid plants from pollen grains. Sci 163:85-87.

Quenzar B, Trifi M, Bouachrine B, Hartmann C, Marrakchi M, Benslimane AA, Rode A (2001). A mitochondrial molecular marker of resistance to Bayoud disease in date palm. Theor Appl Genet 103(2-3):366-370.

Ramsay JL, Galitz DS, Lee CW (2003). Basal medium and sucrose concentration influence regeneration of eastern lily in ovary culture. HortSci 38(3):404-406.

Sedra MH (2011). Development of new Moroccan selected date palm varieties resistant to Bayoud and of good fruit quality, 513-531 p. In: Jain SM, Al-Khayri JM, Johnson DV (Eds.). Date Palm Biotechnology, Springer, Dordrecht.

Sedra MH, Lazrak BH (2011). Fusarium oxysporum f. sp. albedinis toxin characterization and use for selection of resistant date palm to bayoud disease, 253-270 p. In: Jain SM, AlKhayri JM, Johnson DV (Eds.). Date Palm Biotechnology, Springer, Dordrecht.

Wang H, Liu H, Wang W, Zu Y (2008). Effects of Thidiazuron, basal medium and light quality on adventitious shoot regeneration from in vitro cultured stem of Populus alba $\times$ P. berolinensis. J Forest Res 19(3):257-259. 